\title{
Reaction of selected carbohydrate aldehydes with benzyl- magnesium halides: benzyl versus o-tolyl rearrangement
}

\author{
Maroš Bella ${ }^{1}$, Bohumil Steiner ${ }^{1}$, Vratislav Langer ${ }^{2}$ and Miroslav Koóšs ${ }^{* 1}$
}

\section{Full Research Paper}

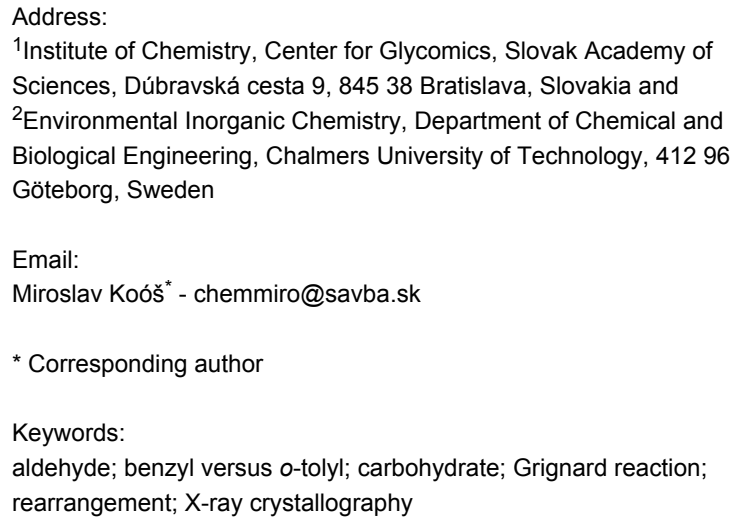

\author{
Beilstein J. Org. Chem. 2014, 10, 1942-1950. \\ doi:10.3762/bjoc. 10.202 \\ Received: 25 May 2014 \\ Accepted: 31 July 2014 \\ Published: 20 August 2014 \\ Associate Editor: S. Flitsch \\ (C) 2014 Bella et al; licensee Beilstein-Institut. \\ License and terms: see end of document.
}

\begin{abstract}
The Grignard reaction of 2,3-O-isopropylidene- $\alpha$-D-lyxo-pentodialdo-1,4-furanoside and benzylmagnesium chloride (or bromide) afforded a non-separable mixture of diastereomeric benzyl carbinols and diastereomeric $o$-tolyl carbinols. The latter resulted from an unexpected benzyl to $o$-tolyl rearrangement. The proportion of benzyl versus $o$-tolyl derivatives depended on the reaction conditions. Benzylmagnesium chloride afforded predominantly $o$-tolyl carbinols while the application of benzylmagnesium bromide led preferably to the $o$-tolyl carbinols only when used in excess or at higher temperatures. The structures of the benzyl and $o$-tolyl derivatives were confirmed unambiguously by NMR spectral data and X-ray crystallographic analysis of their 5-ketone analogues obtained by oxidation of the corresponding mixture of diastereomeric carbinols. A possible mechanism for the Grignard reaction leading to the benzyl $\rightarrow o$-tolyl rearrangement is also proposed.
\end{abstract}

\section{Introduction}

One of the most popular synthetic routes leading to the formation of simple alkyl or aryl branched-chain sugars involves the addition of Grignard reagents. In this regard, a wide variety of Grignard reagents have been added to the free or masked (as hemiacetal) carbonyl functionalities present in the molecule of a suitable fully $O$-protected saccharide, thereby making possible the preparation of a series of useful carbohydrate derivatives [1-8]. Despite the demonstrable advantages of the Grignard reaction, there remain, in addition to the recognised drawbacks, some new unexpected impediments limiting its application in the synthesis of branched carbohydrates.

In the context of our studies on the synthesis of sugar amino acids structurally related to iminosugar mannojirimycin (a strong inhibitor of $\alpha$-mannosidase), we have recently prepared, by applying the Grignard reaction, several branched sugar carbinols as intermediates for subsequent oxidation to ketones affording the corresponding hydantoins (precursors of amino 
acids) via the Bucherer-Bergs reaction in the next step, which were finally transformed into sugar amino acids (precursors of biologicaly active iminosugars). Thus, using methylmagnesium iodide, some alanine-branched sugars were obtained $[9,10]$. Analogously, leucine derivatives were synthesised starting from isobutylmagnesium bromide [11]. Unexpected difficulties were encountered in an attempt to prepare the benzyl-branched sugar carbinol, as a precursor of the final phenylalanine-branched sugar, using benzylmagnesium chloride (1) or benzylmagnesium bromide (2) in the Grignard reaction with 2,3-O-isopropylidene- $\alpha$-D-lyxo-pentodialdo-1,4-furanoside (3). In this case, the corresponding $o$-tolyl derivative was obtained as the major product instead of the expected benzyl compound (Scheme 1). Therefore, this reaction was subjected to more detailed inspection.

\section{Results and Discussion}

Although 1 and $\mathbf{2}$ have frequently been used for the introduction of the benzyl group into a carbohydrate molecule [12-18], the benzyl $\rightarrow o$-tolyl rearrangement has, to the best of our knowledge, only been reported once. In this regard, Panigot and Curley [19] showed that the reaction of 1 with 2,3,4,6-tetra- $O$ acetyl- $\alpha$-D-glucopyranosyl bromide (or chloride) produced a 3:1 mixture of 2-( $\beta$-D-glucopyranosyl)toluene and $(\beta-D-$ glucopyranosyl)phenylmethane isolated as the corresponding 2,3,4,6-tetra- $O$-acetates. However, this is not a case of the typical Grignard reaction where the Grignard reagent is coupled with a carbonyl compound. Moreover, the anomeric position was involved in the reaction and there was an important limitation: the formation of the unexpected $o$-tolyl rearrangement product entailed the participation of both of the equatorially disposed 2- and 6-acetoxy groups present in the substrate. The non-acetylated substrates (like $O$-benzyl) afforded solely nonrearranged benzyl derivatives. Our results represent the situation where the benzyl $\rightarrow o$-tolyl rearrangement occurs during the Grignard reaction between $\mathbf{1}$ or $\mathbf{2}$ and the non-anomeric free aldehyde function (C-5 position of the furanose) of an $O$-alkyl (methyl and isopropylidene)-protected carbohydrate.

First, the addition reaction of aldehyde $\mathbf{3}$ with $\mathbf{1}$ under the standard Grignard reaction conditions (method A, see Experimental part) was examined. Based on the NMR spectral data of the isolated product, a mixture of 5- $(R)$ and 5-(S) $o$-tolyl derivatives 4 and 5 together with a mixture of 5-(R) and 5-(S) benzyl derivatives 6 and 7 (Scheme 1) in the ratio of approximately 3:1 was confirmed, indicating the substantial predominance of the benzyl $\rightarrow o$-tolyl rearrangement. In the subsequent experiments (methods B-E), the influence of the reaction conditions (temperature, reactants ratio, solvent, sequence of reactants addition) was examined, with the aim of suppressing the formation of the rearranged products $\mathbf{4}$ and $\mathbf{5}$. As the preliminary experiments revealed that the addition of a solution of Grignard reagent $\mathbf{2}$ into a solution of the carbohydrate aldehyde $\mathbf{3}$ (i.e., reverse addition of reactants) in the mole ratio of 1.3:1 had some positive effect in respect of the yield (but not of the proportion of isomers) of the Grignard reaction products, we applied these parameters in subsequent experiments. It was found that the application of $\mathbf{2}$ instead of $\mathbf{1}$ also afforded a mixture of $o$-tolyl and benzyl carbinols but their proportion was dependent on the reaction conditions (see Table 1 and Table 2).<smiles>CO[C@H]1OC(C(=O)c2ccccc2C)[C@H](OC)O[C@H]1C(=O)c1ccccc1</smiles> 
The mixture of diastereomeric carbinols 6 and 7 resulted as a main product of the "normal" Grignard reaction only at lower temperature without excess of 2 . Only a minor positive effect on the formation of "normal" addition products $\mathbf{6}$ and $\mathbf{7}$ was observed using 2-methyltetrahydrofuran as a solvent as well as the addition of an equivalent of $\mathrm{CeCl}_{3} \cdot 2 \mathrm{LiCl}$ in THF to the reaction mixture, although it is known that the application of these reagents favours the addition of Grignard reagents to carbonyl compounds to afford higher yields [20-22].

Table 1: Reaction conditions for the Grignard reaction.

\begin{tabular}{|c|c|c|c|}
\hline Method & Entrya & Conditions $^{b}$ & Conditions $^{c}$ \\
\hline$A$ & $1 / 3=3: 1$ & $0.5 \mathrm{~h}, \mathrm{rt}$ & $3 \mathrm{~h}$, reflux \\
\hline B & $2 / 3=1.3: 1$ & $0.5 \mathrm{~h},-25^{\circ} \mathrm{C}$ & $1.5 \mathrm{~h}, \mathrm{rt}$ \\
\hline $\mathrm{C}$ & $2 / 3=2.5: 1$ & $0.5 \mathrm{~h},-25^{\circ} \mathrm{C}$ & $1.5 \mathrm{~h}, \mathrm{rt}$ \\
\hline$D$ & $2 / 3=1.3: 1$ & $0.5 \mathrm{~h}, \mathrm{rt}$ & $2 \mathrm{~h}, \mathrm{rt}$ \\
\hline$E$ & $1 / 3=1.3: 1$ & $0.5 \mathrm{~h},-25^{\circ} \mathrm{C}$ & $1.5 \mathrm{~h}, \mathrm{rt}$ \\
\hline
\end{tabular}

${ }^{a}$ Mole ratio of reagent 1 or $\mathbf{2}$ and aldehyde 3 taken into the Grignard reaction; btime and temperature for addition of reactant $\mathbf{1}$ or $\mathbf{2}$ to $\mathbf{3}$ (in case of method A, reverse addition of reactants was applied, i.e., aldehyde 3 was added to Grignard reagent 1; ' reaction time and temperature after addition of reactants.

Since all attempts to separate and purify carbinols 4-7 using column chromatography were unsuccessful even after acetylation, their physical and spectral data are not given here in detail. In this regard, the ratio of the $R$ and $S$ isomers thus formed has not been studied. However, based on the NMR data (signals for methyl and methylene group of $o$-tolyl and benzyl group, respectively) of the isolated crude mixture of products 4-7, it was possible to determine the relative ratio of $o$-tolyl and benzyl isomers. Finally, for the separation of $o$-tolyl isomer from benzyl isomer, a mixture of all four chromatographically nonseparable isomeric alcohols 4-7 was oxidised using PDC, thereby destroying the chiral center at $\mathrm{C}-5$ position of the saccharide moiety, to afford a mixture of the two corresponding crystalline ketones $\mathbf{8}$ and $\mathbf{9}$. These were successfully separated and purified using column chromatography and recrystallisation. Their structures were established on the basis of ${ }^{1} \mathrm{H}$ and ${ }^{13} \mathrm{C}$ NMR spectral data. The EI mass spectra and the data of elemental analysis were also confirmative. The singlet signal observed for the $\mathrm{H} 1$ atom strongly supports the $\alpha$-configuration at the anomeric atom $\mathrm{C} 1$ with the equatorially positioned $\mathrm{H} 1$ and $\mathrm{H} 2$. A singlet (three protons) at $\delta=3.91$ and a singlet (two protons) at $\delta=2.48$ clearly indicate the methyl (in $o$-tolyl) and methylene (in benzyl) groups, respectively. Finally, the $o$-tolyl structure and benzyl structure of the moieties at C-5 atom of ketone $\mathbf{8}$ (Figure 1) and ketone 9 (Figure 2), respectively, (the numbering of the atoms is in accordance with the numbering recommended by the IUPAC Nomenclature of Carbohydrates [23]) was unambiguously confirmed by singlecrystal X-ray analysis.

The formation of $o$-tolyl isomers $\mathbf{4}$ and $\mathbf{5}$ can be explained by the possible reaction sequence (path 1) depicted in Scheme 2. The first step involves an addition of the Grignard reagent to the saccharide aldehyde, producing a trienic magnesium alkoxide intermediate A (magnesium salt of 2-R-hydroxymethyl-1-methylene-1,2-dihydrobenzene, where $\mathrm{R}$ is the saccharide moiety) which, upon quenching with aqueous $\mathrm{NH}_{4} \mathrm{Cl}$, affords (via an intermediate $\mathbf{B}$ ) the corresponding $o$-tolyl isomer (a mixture of diastereomeric alcohols 4 and 5). A similar mechanism was proposed [24,25] for the reaction of 1-naphthylmethylmagnesium chloride (10) with some aldehydes and ketones (Scheme 3). However, in this case, a trienic magnesium alkoxide intermediate E (magnesium salt of 2-hydroxymethyl-1methylene-1,2-dihydronaphthalene, an analogue of intermediate $\mathbf{A}$ in Scheme 2, path 1), produced by an addition of the Grignard reagent $\mathbf{1 0}$ to the monomeric formaldehyde $\left(\mathbf{1 1}, \mathrm{R}^{1}=\right.$ $\mathrm{R}^{2}=\mathrm{H}$ ), was unstable and decomposed by a reversible process into the Grignard reagent and aldehyde. The latter underwent a Prins-type reaction with the magnesium alkoxide intermediate $\mathbf{E}$ in the presence of $\mathrm{MgCl}_{2}$, to give magnesium salt $\mathbf{G}$ which, upon quenching with aqueous $\mathrm{NH}_{4} \mathrm{Cl}$, affords 1-(2-hydroxyethyl)-2-hydroxymethylnaphthalene $\mathbf{H}$ (an analogue of diol $\mathbf{D}$ in

Table 2: Overall yields of 8 and 9 from oxidation of mixture of carbinols 4-7.

\begin{tabular}{|c|c|c|c|c|c|}
\hline \multirow{2}{*}{ Method } & \multicolumn{2}{|l|}{ Entry $^{a}$} & \multicolumn{2}{|c|}{ Overall yield } & \multirow{2}{*}{$8 / 9$ ratic } \\
\hline & $4-7$ & 8 and 9 & Ketone 8 & Ketone 9 & \\
\hline$A$ & $0.62 \mathrm{~g}$ & $0.59 \mathrm{~g}, 20 \%$ & $0.44 \mathrm{~g}, 15 \%$ & $0.15 \mathrm{~g}, 5 \%$ & $3: 1$ \\
\hline B & $1.37 \mathrm{~g}$ & $1.29 \mathrm{~g}, 44 \%$ & $0.30 \mathrm{~g}, 10 \%$ & $0.99 \mathrm{~g}, 34 \%$ & $1: 3$ \\
\hline $\mathrm{C}$ & $1.17 \mathrm{~g}$ & $1.11 \mathrm{~g}, 38 \%$ & $0.58 \mathrm{~g}, 20 \%$ & $0.53 \mathrm{~g}, 18 \%$ & 1.1:1 \\
\hline$D$ & $0.82 \mathrm{~g}$ & $0.77 \mathrm{~g}, 26 \%$ & $0.56 \mathrm{~g}, 19 \%$ & $0.21 \mathrm{~g}, 7 \%$ & $2.7: 1$ \\
\hline$E$ & $0.96 \mathrm{~g}$ & $0.89 \mathrm{~g}, 30 \%$ & $0.62 \mathrm{~g}, 21 \%$ & $0.27 \mathrm{~g}, 9 \%$ & $2.3: 1$ \\
\hline
\end{tabular}

aAmount of mixture of carbinols 4-7 taken into oxidation obtained from $10 \mathrm{mmol}$ of aldehyde 3 applying methods A-E. 


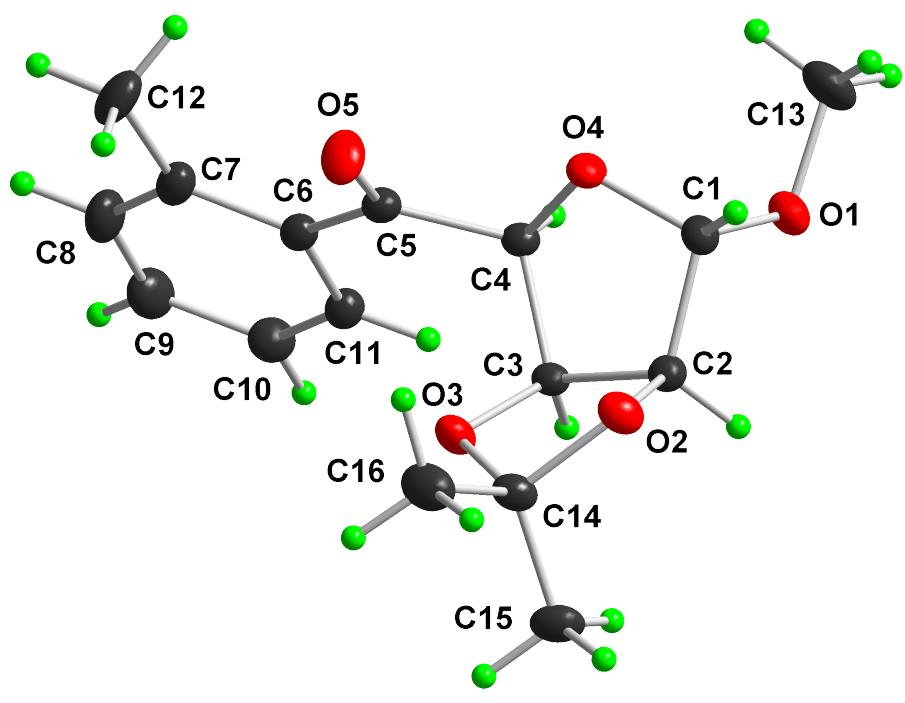<smiles>CO[C@H]1OC(C(=O)c2ccccc2C)C2OC(C)(C)OC21</smiles>

Figure 1: Molecular structure (DIAMOND drawing with adjacent ChemDraw image) of o-tolyl derivative 8. Atomic displacement ellipsoids are drawn at $30 \%$ probability level and $\mathrm{H}$ atoms are shown as small spheres of arbitrary radii.
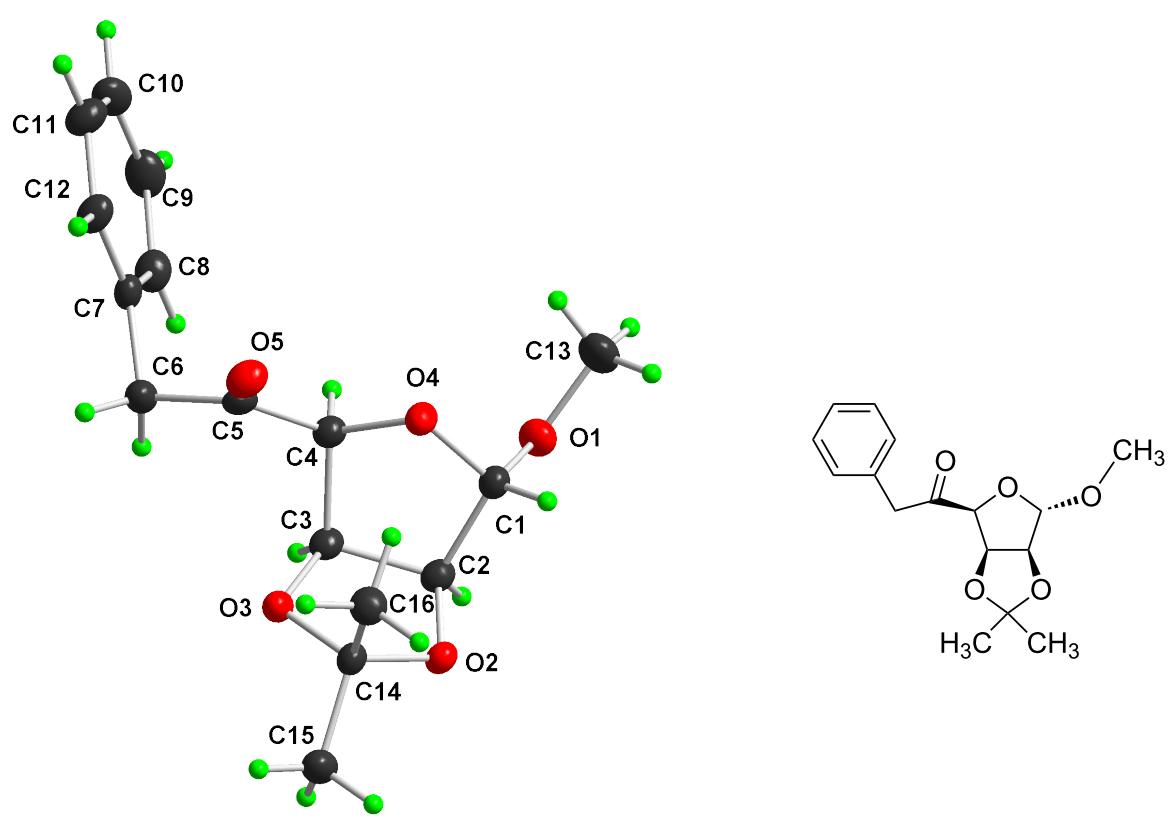

Figure 2: Molecular structure (DIAMOND drawing with adjacent ChemDraw image) of benzyl derivative 9. Atomic displacement ellipsoids are drawn at $50 \%$ probability level and $\mathrm{H}$ atoms are shown as small spheres of arbitrary radii.

Scheme 2, path 2) and 1-methylnaphthalene (12). On the other hand, the reaction of $\mathbf{1 0}$ with ketones produced either normal benzylic alcohols, rearranged alcohols or a mixture of both, depending on the steric hindrance. However, the rearranged alcohols representing 1-methylene-2-substituted-1,2-dihydronaphthalenes $\mathbf{F}$ (analogues of intermediate $\mathbf{B}$ in Scheme 2) were unstable and decomposed to 1-methylnaphthalene (12) and the starting ketone $\mathbf{1 1}$ without the formation (via an intermediate $\mathbf{F}$ ) of 1-methyl-2-substituted-naphthalenes I, analogues of $o$-tolyl derivatives 4 and 5 (Scheme 2, final step of path 1), which were in present study, by contrast, isolated as stable products. Moreover, path 2 in Scheme 2 can be excluded, since no diols of type $\mathbf{C}$ (analogues of diols $\mathbf{H}$ in Scheme 3) were detected in the reaction mixture. 


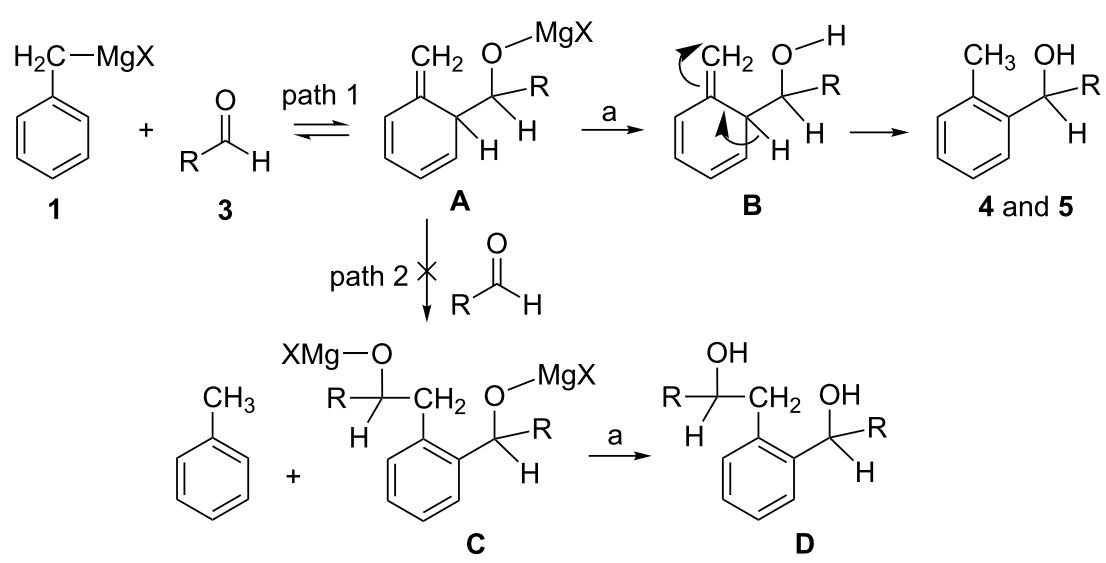

Scheme 2: Proposed mechanism for Grignard reaction leading to benzyl $\rightarrow$-tolyl rearrangement $($ path 1$) . \mathrm{R}=$ saccharide moiety; $a=\mathrm{NH}_{4} \mathrm{Cl}, \mathrm{H}_{2} \mathrm{O}$.

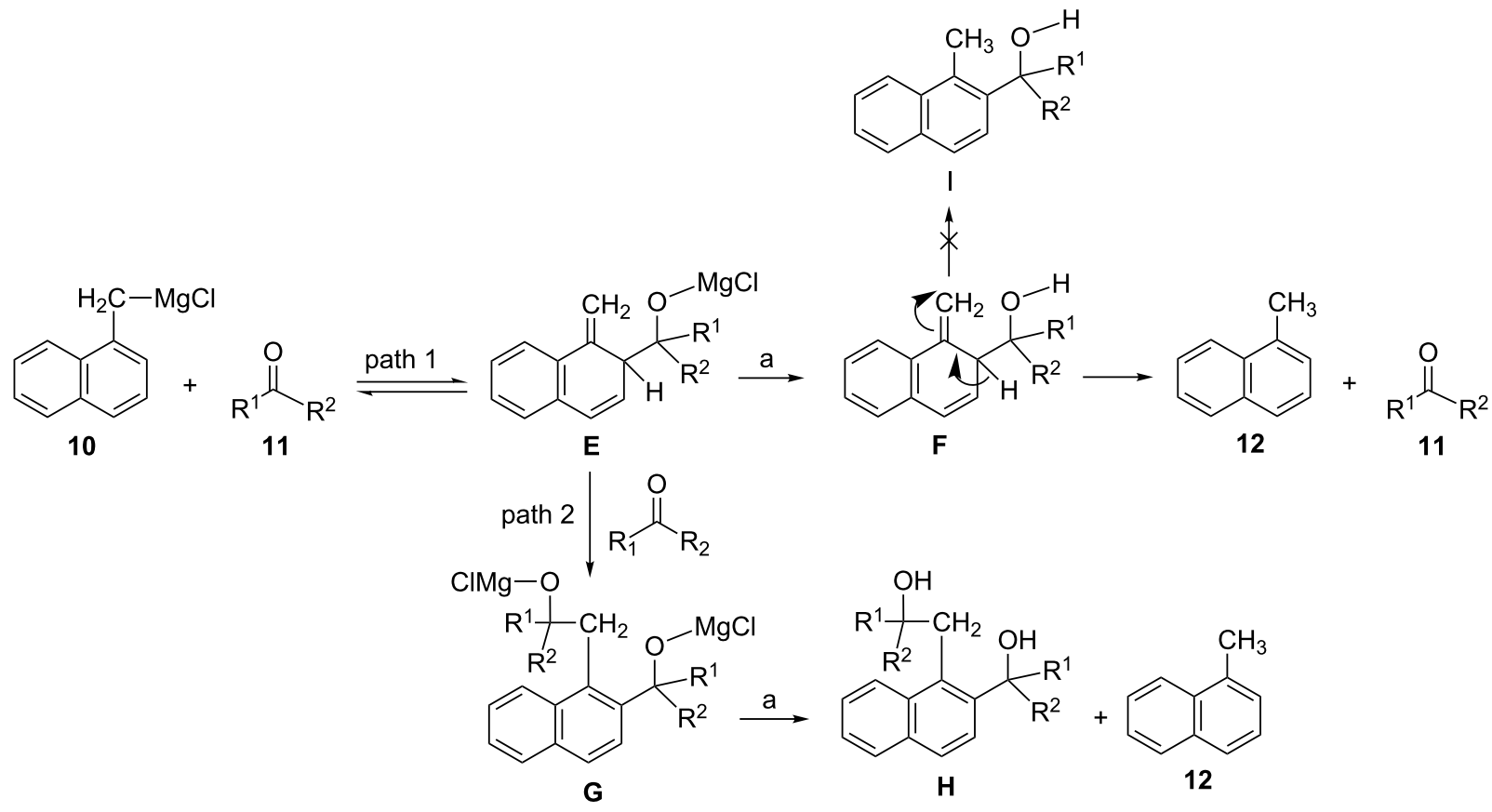

Scheme 3: Proposed mechanism [24,25] for Grignard reaction leading to 1-naphthylmagnesiumchloride $\rightarrow 1$-methylnaphthalene rearrangement. $R_{1}$, $\mathrm{R}_{2}=\mathrm{H}$, alkyl, cycloalkyl, phenyl, benzyl; $\mathrm{a}=\mathrm{NH}_{4} \mathrm{Cl}, \mathrm{H}_{2} \mathrm{O}$.

To extend and confirm these observations, the analogous addition of $\mathbf{1}$ as well as $\mathbf{2}$ to another two representative carbohydrate aldehydes - 3-O-benzyl-1,2-O-isopropylidene- $\alpha$-D- $x y l o$ pentodialdo-1,4-furanose and 1,2:3,4-di- $O$-isopropylidene- $\alpha$-Dgalacto-hexodialdo-1,5-pyranose were investigated next. Unfortunately, only very complex reaction mixtures (including diatereomeric carbinols, biphenyl, polymeric impurities, etc.) resulted under the above reaction conditions. However, analysis of the NMR spectral data of these mixtures showed the absence of $\mathrm{CH}_{3}$ protons of the $o$-tolyl moiety, indicating that the benzyl $\rightarrow o$-tolyl rearrangement did not occur in these cases; accordingly, no further detailed inspections of the reaction mixtures were performed.

\section{X-ray analysis}

Single crystals (stable at ambient temperature) suitable for X-ray diffraction were obtained by the slow crystallisation of $\mathbf{8}$ and 9 from $\mathrm{MeOH}$ by cooling in a refrigerator. The preliminary orientation matrices and final cell parameters were obtained using Siemens SMART and Siemens SAINT software [26]. The data were empirically corrected for absorption and other effects using the SADABS program [27] based on the method of 
Blessing [28]. The crystal and experimental data for 8 and 9 are summarised in Table 3 and Table 4 . The structure was solved by direct methods and refined by full-matrix least-squares on all $F^{2}$ data using Bruker SHELXTL [29]. The non-H atoms were refined anisotropically. All the hydrogen atoms were constrained to the geometrically idealised positions using an appropriate riding model. Molecular graphics were obtained using the program DIAMOND [30].

Table 3: Crystallographic and experimental data ${ }^{a}$ for compound 8

\section{Crystal data}

\begin{tabular}{ll}
\hline Empirical formula & $\mathrm{C}_{16} \mathrm{H}_{20} \mathrm{O}_{5}$ \\
Formula weight & 292.32 \\
Crystal size & $1.00 \times 0.36 \times 0.18 \mathrm{~mm}$ \\
Crystal description & Needle \\
Crystal colour & Colourless \\
Crystal system & Orthorhombic \\
Space group & $P 2{ }_{1}{ }_{1} 2_{1}$ \\
Unit cell dimensions & $a=8.0419(2) \AA$ \\
& $b=10.0156(2) \AA$ \\
Volume & $c=19.2682(3) \AA$ \\
$Z$ & $1551.95(6) \AA$ \\
Calculated density & 4 \\
Absorption coefficient & $1.251 \mathrm{Mg} / \mathrm{m}^{3}$ \\
F(000) & $0.093 \mathrm{~mm}^{-1}$ \\
\end{tabular}

Data collection

\begin{tabular}{ll}
\hline Measurement device type & \multicolumn{1}{l}{ Siemens SMART CCD } \\
Measurement method & $\omega$-scans \\
Temperature & $173(2) \mathrm{K}$ \\
Wavelength & $0.71073 \AA$ \\
Monochromator & Graphite \\
$\theta$ range for data collection & 2.11 to $28.33^{\circ}$ \\
Index ranges & $-10 \leq h \leq 10$, \\
& $-13 \leq k \leq 13$, \\
& $-25 \leq I \leq 25$ \\
Reflections collected/unique & $21019 / 2217$ [ $R($ int $)=0.0496]$ \\
Completeness to $\theta=28.33^{\circ}$ & $99.7 \%$ \\
Absorption correction & Multi-scan \\
Max. and min. transmission & 0.9835 and 0.9132 \\
& \\
\hline Refinement & \\
\hline Refinement method & Full-matrix least-squares on \\
& $F^{2}$ \\
Data/restraints/parameters & $2217 / 0 / 214$ \\
Goodness-of-fit on $F^{2}$ & 1.025 \\
Final $R$ indices [ $/>2 \sigma(I)]$ & $R_{1}=0.0322, w R_{2}=0.0797$ \\
$R$ indices (all data) & $R_{1}=0.0398, w R_{2}=0.0850$ \\
Largest diff. peak and hole & 0.198 and -0.149 e. $\AA^{-3}$ \\
\hline aStandard deviations in parentheses. \\
\end{tabular}

Table 4: Crystallographic and experimental data ${ }^{\mathrm{a}}$ for compound 9.

Crystal data

\begin{tabular}{ll}
\hline Empirical formula & $\mathrm{C}_{16} \mathrm{H}_{20} \mathrm{O}_{5}$ \\
Formula weight & 292.32 \\
Crystal size & $0.98 \times 0.21 \times 0.12 \mathrm{~mm}$ \\
Crystal description & Needle \\
Crystal colour & Colourless \\
Crystal system & Monoclinic \\
Space group & $P 2_{1}$ \\
Unit cell dimensions & $a=10.5035(14) \AA$ \\
& $b=5.7075(8) \AA$ \\
& $\beta=96.268(3)^{\circ}$ \\
Volume & $c=12.3449(16) \AA$ \\
$Z$ & $735.64(17) \AA^{3}$ \\
Calculated density & 2 \\
Absorption coefficient & $1.320{\mathrm{Mg} / \mathrm{m}^{3}}^{-}$ \\
F(000) & $0.098 \mathrm{~mm}^{-1}$ \\
\end{tabular}

Data collection

\begin{tabular}{ll}
\hline Measurement device type & $\begin{array}{l}\text { Siemens SMART CCD } \\
\text { Measurement method }\end{array}$ \\
$\begin{array}{l}\text { Temperature } \\
\text { Tems }\end{array}$ \\
Wavelength & $0.71073 \AA$ \\
Monochromator & Graphite \\
Theta range for data & 2.42 to $29.20^{\circ}$ \\
collection & $-14 \leq h \leq 14$, \\
Index ranges & $-7 \leq k \leq 7$, \\
& $-16 \leq I \leq 16$ \\
Reflections collected/unique & $10030 / 2175[R($ int $)=0.0516]$ \\
Completeness to $\theta=29.20^{\circ}$ & $99.4 \%$ \\
Absorption correction & Multi-scan \\
Max. and min. transmission & 0.9884 and 0.9104
\end{tabular}

Refinement

\begin{tabular}{ll}
\hline Refinement method & $\begin{array}{l}\text { Full-matrix least-squares on } \\
\end{array}$ \\
$F^{2}$ \\
Data/restraints/parameters & $2175 / 1 / 193$ \\
Goodness-of-fit on $F^{2}$ & 1.002 \\
Final $R$ indices $[>2 \sigma(\mathrm{I})]$ & $R_{1}=0.0329, w R_{2}=0.0802$ \\
$R$ indices (all data) & $R_{1}=0.0411, w R_{2}=0.0842$ \\
Largest diff. peak and hole & 0.188 and $-0.195 e \cdot \AA^{-3}$ \\
\hline aStandard deviations in parentheses.
\end{tabular}

Based on the calculated values of the ring-puckering parameters $(Q, \Phi, \theta)$ [31] (Table 5) and relevant torsion angles (Table 6), the conformations of the five-membered $\mathrm{O} 4-\mathrm{C} 1-\mathrm{C} 2-\mathrm{C} 3-\mathrm{C} 4$ furanose ring and the five-membered 1,3dioxolane ring (O2-C2-C3-O3-C14) in compounds 8 and 9 were established. It was found that the furanose ring in $\mathbf{8}$ adopted the ${ }^{\mathrm{O}} E\left({ }^{\mathrm{O}} E\right)$ conformation distorted significantly to the 
${ }^{\mathrm{O}} T_{1}\left({ }^{\mathrm{O} 4} T_{\mathrm{C} 1}\right.$, twisted on $\left.\mathrm{O} 4-\mathrm{C} 1, \mathrm{O} 4-e n d o\right)$ direction. The conformation of the five-membered 1,3-dioxolane ring in 8 can be described as a ${ }^{4} E\left({ }^{\mathrm{C} 14} E\right)$ shifted significantly to the ${ }^{4} T_{\mathrm{O}}$ $\left({ }^{\mathrm{C} 14} T_{\mathrm{O} 2}\right.$, twisted on $\left.\mathrm{C} 14-\mathrm{O} 2, \mathrm{C} 14-e n d o\right)$ direction. Regarding compound 9, an inspection of the relevant data revealed an almost perfect ${ }^{\mathrm{O}} E\left({ }^{\mathrm{O} 4} E\right)$ conformation of the furanose ring and the $E_{4}\left(E_{\mathrm{C} 14}\right)$ conformation distorted significantly to the ${ }^{\mathrm{O}} T_{4}$ $\left({ }^{\mathrm{O} 2} T_{\mathrm{C} 14}\right.$, twisted on $\mathrm{O} 2-\mathrm{C} 14, \mathrm{C} 14-$ exo $)$ direction of the 1,3dioxolane ring.

$\begin{aligned} & \text { Table 5: Puckering parameters }{ }^{\text {a }} \text { for the five-membered furanose ring } \\
& \text { and the five-membered 1,3-dioxolane ring in compounds } \mathbf{8} \text { and } \mathbf{9 .}\end{aligned}$
\begin{tabular}{llll} 
Ring & Parameter & Compound \\
\cline { 3 - 4 } & & $\mathbf{8}$ & $\mathbf{9}$ \\
\hline Furanose & $Q(\AA)$ & $0.3467(16)$ & $0.3206(16)$ \\
1,3-Dioxolane & $\Phi\left({ }^{\circ}\right)$ & $8.1(3)$ & $353.8(9)$ \\
& $Q(\AA)$ & $0.3299(16)$ & $0.2146(16)$ \\
& $\Phi\left({ }^{\circ}\right)$ & $155.1(3)$ & $332.9(4)$ \\
\hline
\end{tabular}

aStandard deviations in parentheses.

Table 6: Relevant torsion angles $\left({ }^{\circ}\right)^{a}$ for the five-membered furanose ring and the five-membered 1,3-dioxolane ring in compounds 8 and $\mathbf{9}$.

\begin{tabular}{llll}
\multirow{2}{*}{ Ring } & Torsion angle & \multicolumn{2}{l}{ Compound } \\
\cline { 3 - 4 } & & $\mathbf{8}$ & $\mathbf{9}$ \\
\hline \multirow{2}{*}{ Furanose } & O4-C1-C2-C3 & $26.34(16)$ & $17.62(18)$ \\
& C1-C2-C3-C4 & $-5.02(16)$ & $3.34(18)$ \\
& C2-C3-C4-O4 & $-17.45(15)$ & $-23.03(17)$ \\
& C3-C4-O4-C1 & $35.47(15)$ & $35.73(16)$ \\
1,3-Dioxolane & O2-C2-C3-O3 & $-6.58(16)$ & $3.57(18)$ \\
& C2-C3-O3-C14 & $-16.04(16)$ & $11.31(17)$ \\
& C3-O3-C14-O2 & $32.66(16)$ & $-21.76(17)$ \\
& O3-C14-O2-C2 & $-37.19(16)$ & $24.23(17)$ \\
& C14-O2-C2-C3 & $26.66(16)$ & $-17.24(17)$ \\
\hline
\end{tabular}

aStandard deviations in parentheses.

\section{Conclusion}

In summary, various reaction conditions were employed for the synthesis of carbinols 4-7 from Grignard reagent 1 (or 2) and sugar aldehyde 3 . Depending on the reaction conditions, the ratio of $o$-tolyl carbinols 4 and 5 (products of the benzyl $\rightarrow o$ tolyl rearrangement) versus non-rearranged benzyl carbinols 6 and 7 varied from 3:1 to 1:3 (based on the isolated $o$-tolyl and benzyl ketones $\mathbf{8}$ and $\mathbf{9}$, respectively). It seems that the benzyl $\rightarrow O$-tolyl rearrangement is specific for 2,3-O-isopropylidene- $\alpha$-D-lyxo-pentodialdo-1,4-furanoside because no rearrangement was observed when 3-O-benzyl-1,2-O-isopropyli- dene- $\alpha$-D-xylo-pentodialdo-1,4-furanose and 1,2:3,4-di- $O$-isopropylidene- $\alpha$-D-galacto-hexodialdo-1,5-pyranose were used as starting sugar aldehydes. The structures of $o$-tolyl and benzyl derivatives $\mathbf{8}$ and $\mathbf{9}$ were unambiguously confirmed by X-ray crystallographic analysis. Compounds $\mathbf{8}$ and $\mathbf{9}$ represent profitable synthetic blocks for the synthesis of structurally modified iminosugars and sugar moiety-containing heterocycles, amino acids, etc.

\section{Experimental}

Reagents and apparatus: The starting methyl 2,3-O-isopropylidene- $\alpha$-D-lyxo-pentodialdo-1,4-furanoside was prepared according to a recognised method [32,33]. Benzylmagnesium chloride (1) and benzylmagnesium bromide (2) solutions (1 M in diethyl ether) and the other reagents and solvents were commercially available products and were used as received. Melting points were determined using a Boetius PHMK 05 microscope. Specific rotations were determined on a Jasco P-2000 digital polarimeter. Microanalyses were performed on a Fisons EA 1108 analyser. The ${ }^{1} \mathrm{H}$ and ${ }^{13} \mathrm{C}$ NMR spectra (in $\mathrm{CDCl}_{3}$, internal standard $\mathrm{Me}_{4} \mathrm{Si}$ ) were recorded on a Varian $600 \mathrm{MHz}$ VNMRS spectrometer equipped with $\mathrm{HCN}{ }^{13} \mathrm{C}$ enhanced salt-tolerant cold probe operating at 599.84 and 150.84 MHz working frequencies, respectively. Advanced techniques from the Varian pulse sequence library of 2D homo- and hetero-correlated spectroscopy (gCOSY, gTOCSY, gHSQCAD, gHMBCAD, and gH2BC) including 1D sequences with selective excitations (1DNOESY, 1DTOCSY, and 1DROESY) were used for the signal assignments. The quaternary carbon atoms were identified on the basis of a semi-selective INEPT experiment and a 1D INADEQUATE pulse sequence technique. When reporting assignments of NMR signals, the data for the phenyl moiety are identified by a prime. The EI mass spectra $(70 \mathrm{eV})$ were obtained on a Q-Tof Premier instrument (Waters). Column chromatography was performed as flash chromatography on Silica Gel 60 (E. Merck, 0.063-0.200 mm). The IR spectra (ATR) were measured using a Nicolet 6700 FTIR spectrometer. Thin-layer chromatography was performed on precoated Silica Gel 60 F254 plates (E. Merck). Visualisation was achieved by spraying the plates with $5 \%(\mathrm{v} / \mathrm{v})$ solution of $\mathrm{H}_{2} \mathrm{SO}_{4}$ in ethanol and heating at ca $200{ }^{\circ} \mathrm{C}$.

Synthesis of methyl (5R)-2,3-O-isopropylidene-5-C-(2methylphenyl)- $\alpha$-D-lyxofuranoside (4), methyl (5S)-2,3- $O$ isopropylidene-5-C-(2-methylphenyl)- $\alpha$-D-lyxofuranoside (5), methyl 6-deoxy-2,3-O-isopropylidene-6-phenyl- $\alpha$-Dmannofuranoside (6), and methyl 6-deoxy-2,3-O-isopropylidene-6-phenyl- $\beta$-L-gulofuranoside (7)

Method A: Methyl 2,3-O-isopropylidene- $\alpha$-D-lyxo-pentodialdo-1,4-furanoside (3) (2.02 g, $10.0 \mathrm{mmol})$ in diethyl ether 
$(30 \mathrm{~mL})$ was added dropwise into benzylmagnesium chloride $(1,1.0 \mathrm{M}$ solution in diethyl ether, $13 \mathrm{~mL}, 13 \mathrm{mmol}$ ) at ambient temperature in the course of $30 \mathrm{~min}$. Subsequently, the mixture was stirred and heated under reflux for $3 \mathrm{~h}$. After cooling, it was poured into a saturated $\mathrm{NH}_{4} \mathrm{Cl}$ solution pre-cooled to $5{ }^{\circ} \mathrm{C}$. The organic layer was separated and the aqueous layer was extracted with diethyl ether $(3 \times 50 \mathrm{~mL})$. The combined organic layers were dried $\left(\mathrm{Na}_{2} \mathrm{SO}_{4}\right)$, filtered and evaporated under reduced pressure to give a crude oily product which was purified on a column of silica gel using EtOAc/hexane 1:4 as an eluent, affording a mixture of alcohols 4-7 $\left(R_{\mathrm{f}}=0.44,0.62 \mathrm{~g}\right.$, $21 \%)$.

Method B: Benzylmagnesium bromide (2, 1.0 M solution in diethyl ether, $13 \mathrm{~mL}, 13 \mathrm{mmol}$ ) pre-cooled to $-5^{\circ} \mathrm{C}$ was added dropwise to a magnetically stirred solution of aldehyde $\mathbf{3}$ $(2.02 \mathrm{~g}, 10.0 \mathrm{mmol})$ in diethyl ether $(30 \mathrm{~mL})$ under cooling at $-25{ }^{\circ} \mathrm{C}$ in the course of $30 \mathrm{~min}$. Subsequently, the mixture was stirred at ambient temperature for an additional $1.5 \mathrm{~h}$ and poured into a saturated $\mathrm{NH}_{4} \mathrm{Cl}$ solution pre-cooled to $5{ }^{\circ} \mathrm{C}$. The organic layer was separated and the aqueous layer was extracted with diethyl ether $(3 \times 50 \mathrm{~mL})$. The combined organic layers were dried $\left(\mathrm{Na}_{2} \mathrm{SO}_{4}\right)$, filtered and evaporated under reduced pressure to give a crude oily product which was purified on a column of silica gel using EtOAc/hexane 1:4 as an eluent, affording a mixture of alcohols 4-7 $\left(R_{\mathrm{f}}=0.44,1.37 \mathrm{~g}\right.$, $46 \%)$.

Method C: Benzylmagnesium bromide (2, 1.0 $\mathrm{M}$ solution in diethyl ether, $25 \mathrm{~mL}, 25 \mathrm{mmol})$ and aldehyde $3(2.02 \mathrm{~g}$, $10.0 \mathrm{mmol})$ in diethyl ether $(30 \mathrm{~mL})$ were allowed to react under the same reaction conditions as in method B to give (after column chromatography) a mixture of alcohols 4-7 $\left(R_{\mathrm{f}}=0.44\right.$, $1.17 \mathrm{~g}, 39.5 \%)$.

Method D: Benzylmagnesium bromide (2, 1.0 M solution in diethyl ether, $13 \mathrm{~mL}, 13 \mathrm{mmol})$ and aldehyde $3(2.02 \mathrm{~g}$, $10.0 \mathrm{mmol})$ in diethyl ether $(30 \mathrm{~mL})$ were allowed to react at ambient temperature applying the reaction mixture work-up procedure as in method B to give (after column chromatography) a mixture of alcohols $4-7\left(R_{\mathrm{f}}=0.44,0.82 \mathrm{~g}, 28 \%\right)$.

Method E: Benzylmagnesium chloride (1, 1.0 M solution in diethyl ether, $13 \mathrm{~mL}, 13 \mathrm{mmol})$ and aldehyde 3 (2.02 g, $10.0 \mathrm{mmol})$ in diethyl ether $(30 \mathrm{~mL})$ were allowed to react under the same reaction conditions as in method B to give (after column chromatography) a mixture of alcohols 4-7 $\left(R_{\mathrm{f}}=0.44\right.$, $0.96 \mathrm{~g}, 33 \%)$.

Synthesis of methyl 2,3-O-isopropylidene-5-C-(2methylphenyl)- $\alpha$-D-lyxo-pentodialdo-1,4-furanoside (8) and methyl 6-deoxy-2,3-O-isopropylidene-6-phenyl- $\alpha$-D-lyxohexofuranosid-5-ulose (9): A mixture of alcohols 4-7 (1.47 g, $5.0 \mathrm{mmol})$ in $\mathrm{CH}_{2} \mathrm{Cl}_{2}(25 \mathrm{~mL})$ was added dropwise to a magnetically stirred solution of pyridinium dichromate (PDC, $2.45 \mathrm{~g}$, $6.5 \mathrm{mmol})$ and acetic anhydride $(1.3 \mathrm{~mL})$ in $\mathrm{CH}_{2} \mathrm{Cl}_{2}(25 \mathrm{~mL})$ under cooling in an ice-water bath followed by heating under reflux for $3 \mathrm{~h}$. The greater part of $\mathrm{CH}_{2} \mathrm{Cl}_{2}$ was evaporated and the chromic salts were precipitated by the addition of a mixture of EtOAc/hexane 1:1. After filtration and evaporation of the solvents under reduced pressure, the product thus obtained was purified on a column of silica gel using EtOAc/hexane 1:4 as an eluent, affording ketone $8\left(R_{\mathrm{f}}=0.6\right)$ and ketone $9\left(R_{\mathrm{f}}=0.7\right)$ with a total yield of $94-96 \%$ (percentage of 8 and 9 together in oxidation step). These were recrystallised from methanol. The overall isolated yields of $\mathbf{8}$ and $\mathbf{9}$ (depending on the method used for preparation of the starting mixture of alcohols 4-7) from two reaction steps (Grignard reaction and PDC oxidation) starting from $10 \mathrm{mmol}$ of aldehyde 3 are summarised in Table 2 .

8: colourless solid; $\mathrm{mp} 105-106{ }^{\circ} \mathrm{C} ;[\alpha]_{\mathrm{D}}^{22}+12(c 1, \mathrm{MeOH})$; ${ }^{1} \mathrm{H}$ NMR (600 MHz, $\left.\mathrm{CDCl}_{3}\right) \delta$ 7.60-7.22 (m, 5H, Ph), $5.26(\mathrm{~d}$, $\left.J_{3,4}=4.3 \mathrm{~Hz}, 1 \mathrm{H}, \mathrm{H}-4\right), 5.12(\mathrm{~s}, 1 \mathrm{H}, \mathrm{H}-1), 4.99\left(\mathrm{dd}, J_{2,3}=5.7\right.$ $\left.\mathrm{Hz}, J_{3,4}=4.3 \mathrm{~Hz}, 1 \mathrm{H}, \mathrm{H}-3\right), 4.58\left(\mathrm{~d}, J_{2,3}=5.7 \mathrm{~Hz}, 1 \mathrm{H}, \mathrm{H}-2\right)$, $3.41\left(\mathrm{~s}, 3 \mathrm{H}, \mathrm{OCH}_{3}\right), 2.48\left(\mathrm{~s}, 3 \mathrm{H}, \mathrm{CH}_{3}\right), 1.41$ and $1.21(2 \mathrm{~s}$, each $\left.3 \mathrm{H}, \mathrm{Me}_{2} \mathrm{C}\right) \mathrm{ppm} ;{ }^{13} \mathrm{C} \mathrm{NMR}\left(150 \mathrm{MHz}, \mathrm{CDCl}_{3}\right) \delta 196.7(\mathrm{C}-5)$, 138.6 (C-2'), 136.7 (C-1'), 131.8 (C-6'), 131.2 (C-4'), 127.4 (C-3'), $125.3\left(\mathrm{C}-5^{\prime}\right), 113.3\left(\mathrm{CMe}_{2}\right), 107.2(\mathrm{C}-1), 84.4(\mathrm{C}-2)$, $83.8(\mathrm{C}-4), 81.0(\mathrm{C}-3), 55.1\left(\mathrm{OCH}_{3}\right), 25.8$ and $25.0\left[\left(\mathrm{CH}_{3}\right)_{2} \mathrm{C}\right]$, $20.3\left(\mathrm{CH}_{3}\right) \mathrm{ppm}$; EIMS m/z (I $/ \%$ ): 292 (5), 277 (20), 261 (10), 203 (20), 192 (100), 173 (38), 161 (34), 145 (16), 119 (95), 115 (11), 113 (6), 91 (18), 43 (50); IR (ATR) v: 2987, 2928, 2834, $1695(\mathrm{C}=\mathrm{O}), 1602,1569,1487,1453,1379,1278,1205,1163$, 1110, 1088, 1072, 1011, 964, 922, 886, 856, 825, 784, 761, 729, $659,647,619,591 \mathrm{~cm}^{-1}$; anal. calcd $(\%)$ for $\mathrm{C}_{16} \mathrm{H}_{20} \mathrm{O}_{5}$ (292.33): C, 65.70; H, 6.90; found (\%): C, 65.56; H, 6.81.

9: colourless solid; mp $72-73{ }^{\circ} \mathrm{C} ;[\alpha]_{\mathrm{D}}^{22}+5(c 1, \mathrm{MeOH}) ;{ }^{1} \mathrm{H}$ NMR (600 MHz, $\left.\mathrm{CDCl}_{3}\right) \delta$ 7.33-7.21 (m, 5H, Ph), $5.07(\mathrm{~s}, 1 \mathrm{H}$, $\mathrm{H}-1), 4.99$ (dd, $\left.J_{2,3}=5.7 \mathrm{~Hz}, J_{3,4}=4.2 \mathrm{~Hz}, 1 \mathrm{H}, \mathrm{H}-3\right), 4.56$ (d, $\left.J_{2,3}=5.7 \mathrm{~Hz}, 1 \mathrm{H}, \mathrm{H}-2\right), 4.50$ (d, $\left.J_{3,4}=4.2 \mathrm{~Hz}, 1 \mathrm{H}, \mathrm{H}-4\right), 3.91$ $(\mathrm{s}, 2 \mathrm{H}, \mathrm{H}-6), 3.32\left(\mathrm{~s}, 3 \mathrm{H}, \mathrm{OCH}_{3}\right), 1.45$ and $1.28(2 \mathrm{~s}$, each $3 \mathrm{H}$, $\left.\mathrm{Me}_{2} \mathrm{C}\right) \mathrm{ppm} ;{ }^{13} \mathrm{C} \mathrm{NMR}\left(150 \mathrm{MHz}, \mathrm{CDCl}_{3}\right) \delta 203.7$ (C-5), 133.5 (C-1'), 129.9 (C-3', C-5'), 128.5 (C-2', C-6'), 126.9 (C-4'), 113.1 $\left(\mathrm{CMe}_{2}\right), 107.6$ (C-1), 84.4 (C-4), 84.2 (C-2), 81.0 (C-3), 55.0 (OCH3), 47.1 (C-6), 25.8 and $24.5\left[\left(\mathrm{CH}_{3}\right)_{2} \mathrm{C}\right] \mathrm{ppm}$; EIMS $\mathrm{m} / \mathrm{z}$ $\left(I_{\mathrm{r}} / \%\right): 292$ (5), 277 (5), 203 (36), 192 (21), 173 (13), 161 (15), 115 (20), 113 (19), 99 (21), 91 (100), 87 (17), 85 (14), 83 (6), 65 (11), 59 (16), 55 (8), 45 (31), 43 (30), 41 (9); IR (ATR) v: 2992, 2937, 2868, 2838, 1722, 1600, 1493, 1456, 1433, 1377, 1263, 1238, 1209, 1154, 1121, 1091, 1060, 1029, 996, 968, 874, 
$798,753,720,699,658,611,560,513 \mathrm{~cm}^{-1}$; anal. calcd (\%) for $\mathrm{C}_{16} \mathrm{H}_{20} \mathrm{O}_{5}$ (292.33): C, 65.70; H, 6.90; found (\%): C, 65.52; $\mathrm{H}, 7.01$.

Crystallographic data for structures $\mathbf{8}$ and $\mathbf{9}$ have been deposited with the Cambridge Crystallographic Data Centre as supplementary publication nos. CCDC 1001956 and 1001957. Copies of the data can be obtained, free of charge, on application to CCDC, 12 Union Road, Cambridge, CB2 1EZ, UK (fax: + 44-(0)1223-336033 or e-mail: deposit@ccdc.cam.ac.uk or via: http://www.ccdc.cam.ac.uk).

\section{Acknowledgements}

The financial support from the Slovak Research and Development Agency (Grant no. APVV-0484-12) and Scientific Grant Agency (Grant nos. VEGA 2/0101/11 and 1/0962/12) is gratefully acknowledged. This contribution is the result of the project implementation: Centre of Excellence for Glycomics, ITMS 26240120031, supported by the Research \& Development Operational Programme funded by the ERDF.

\section{References}

1. Bonner, W. A. Methods Carbohydr. Chem. 1963, 2, 465-473.

2. Böshagen, H.; Geiger, W.; Junge, B. Angew. Chem., Int. Ed. Engl. 1981, 20, 806-807. doi:10.1002/anie.198108061

3. Kakinuma, K.; lihama, Y.; Takagi, I.; Ozawa, K.; Yamauchi, N.; Imamura, N.; Esumi, Y.; Uramoto, M. Tetrahedron 1992, 48, 3763-3774. doi:10.1016/S0040-4020(01)92267-7

4. López, J. C.; Lameignère, E.; Burnouf, C.; de Los Angeles Laborde, M.; Ghini, A. A.; Olesker, A.; Lukacs, G. Tetrahedron 1993, 49, 7701-7722. doi:10.1016/S0040-4020(01)87245-8

5. Schmeichel, M.; Redlich, H. Synthesis 1996, 1002-1006. doi:10.1055/s-1996-4321

6. Grzeszczyk, B.; Zamojski, A. Collect. Czech. Chem. Commun. 2000, 65, 610-620. doi:10.1135/cccc20000610

7. Gustafsson, T.; Saxin, M.; Kihlberg, J. J. Org. Chem. 2003, 68, 2506-2509. doi:10.1021/jo026758d

8. Jennings, M. P.; Clemens, R. T. Tetrahedron Lett. 2005, 46, 2021-2024. doi:10.1016/j.tetlet.2005.01.156

9. Koóš, M.; Steiner, B.; Mičová, J.; Langer, V.; Ďurík, M.; Gyepesová, D. Carbohydr. Res. 2001, 332, 351-361. doi:10.1016/S0008-6215(01)00109-4

10. Mičová, J.; Steiner, B.; Koóš, M.; Langer, V.; Ďurík, M.; Gyepesová, D.; Smrčok, L'. Carbohydr. Res. 2002, 337, 663-672. doi:10.1016/S0008-6215(02)00058-7

11. Steiner, B.; Mičová, J.; Koóš, M.; Langer, V.; Gyepesová, D. Carbohydr. Res. 2003, 338, 1349-1357. doi:10.1016/S0008-6215(03)00176-9

12. Periers, A.-M.; Laurin, P.; Benedetti, Y.; Lachaud, S.; Ferroud, D.; Iltis, A.; Haesslein, J.-L.; Klich, M.; L'Hermite, G.; Musicki, B. Tetrahedron Lett. 2000, 41, 867-871. doi:10.1016/S0040-4039(99)02177-2

13. Chapman, T. M.; Courtney, S.; Hay, P.; Davis, B. G. Chem. - Eur. J. 2003, 9, 3397-3414. doi:10.1002/chem.200304718
14. Reetz, M. T. Angew. Chem., Int. Ed. Engl. 1984, 23, 556-569. doi:10.1002/anie.198405561

15. Yang, W.-B.; Yang, Y.-Y.; Gu, Y.-F.; Wang, S.-H.; Chang, C.-C.; Lin, C.-H. J. Org. Chem. 2002, 67, 3773-3782. doi:10.1021/jo0255227

16. Yang, Y.-L.; Falck, J. R. Tetrahedron Lett. 1982, 23, 4305-4308. doi:10.1016/S0040-4039(00)85585-9

17. Dondoni, A.; Perrone, D.; Rinaldi, M. J. Org. Chem. 1998, 63, 9252-9264. doi:10.1021/jo980980u

18. Lindbäck, E.; Zhou, Y.; Marinescu, L.; Pedersen, C. M.; Bols, M. Eur. J. Org. Chem. 2010, 3883-3896. doi:10.1002/ejoc.201000295

19. Panigot, M. J.; Curley, R. W., Jr. J. Carbohydr. Chem. 1994, 13, 293-302. doi:10.1080/07328309408009194

20. Zhong, W.; Wu, Y.; Zhang, X. J. Chem. Res. 2009, 370-373. doi:10.3184/030823409X460939

21. Jiao, P.; Kawasaki, M.; Yamamoto, H. Angew. Chem., Int. Ed. 2009, 48, 3333-3336. doi:10.1002/anie.200900682

22. Krasovskiy, A.; Kopp, F.; Knochel, P. Angew. Chem., Int. Ed. 2006, 45, 497-500. doi:10.1002/anie.200502485

23. McNaught, A. D. Pure Appl. Chem. 1996, 68, 1919-2008. doi:10.1351/pac199668101919

24. Bernardon, C.; Deberly, A. J. Chem. Soc., Perkin Trans. 11980 , 2631-2636. doi:10.1039/P19800002631

25. Bernardon, C.; Deberly, A. J. Org. Chem. 1982, 47, 463-468. doi:10.1021/jo00342a018

26. SMART \& SAINT; Bruker AXS Inc.: Madison, WI, USA, 2003.

27. SADABS, Version 2.10; University of Göttingen: Germany, 2003.

28. Blessing, R. H. Acta Crystallogr., Sect. A 1995, 51, 33-38.

29. SHELXTL, Version 6.10; Bruker AXS Inc.: Madison, WI, USA, 2001.

30. DIAMOND: Visual Crystal Structure Information System, Version 3.1f; Crystal Impact GbR: Bonn, Germany, 2010.

31. Cremer, D.; Pople, J. A. J. Am. Chem. Soc. 1975, 97, 1354-1358. doi:10.1021/ja00839a011

32. Krajewski, J. W.; Gluziński, P.; Pakulski, Z.; Zamojski, A.; Mishnev, A.; Kemme, A. Carbohydr. Res. 1994, 252, 97-105. doi:10.1016/0008-6215(94)90008-6

33. Barton, D. H. R.; Géro, S. D.; Quiclet-Sire, B.; Samadi, M. Tetrahedron: Asymmetry 1994, 5, 2123-2136. doi:10.1016/s0957-4166(00)86288-6

\section{License and Terms}

This is an Open Access article under the terms of the Creative Commons Attribution License (http://creativecommons.org/licenses/by/2.0), which permits unrestricted use, distribution, and reproduction in any medium, provided the original work is properly cited.

The license is subject to the Beilstein Journal of Organic Chemistry terms and conditions: (http://www.beilstein-journals.org/bjoc)

The definitive version of this article is the electronic one which can be found at:

$\underline{\text { doi:10.3762/bjoc. } 10.202}$ 